\title{
KARAKTERISTIK, ASPIRASI, DAN MEDIA INFORMASI DALAM MUSRENBANG DESA/KELURAHAN DI KOTA BANJAR JAWA BARAT
}

\author{
Adhi Iman Sulaiman', Djuara P. Lubis ${ }^{2}$, Djoko Susanto ${ }^{3}$, Ninuk Purnaningsih ${ }^{4}$ \\ ${ }^{1}$ Fakultas Ilmu Sosial dan Ilmu Politik, Universitas Jenderal Soedirman \\ Jl. Prof. Bunyamin No. 993, Purwokerto, Jawa Tengah \\ 2, 3,4 Departemen Sain Komunikasi dan Pengembangan Masyarakat, Pascasarjana, Institut Pertanian Bogor \\ Kampus IPB Darmaga Bogor, Jawa Barat \\ No. Telp./HP: ${ }^{1} 081313220202,{ }^{2} 08128194904,{ }^{3} 08121100728,{ }^{4} 081317095618$ \\ E-mail: ${ }^{1}$ adhi_iman@yahoo.com, ${ }^{2}$ djuaralubis@gmail.com, ${ }^{3}$ kmpipb@yahoo.com, ${ }^{4}$ npurnaningsih@gmail.com
}

Naskah diterima tanggal 15 Februari 2016, direvisi tanggal 6 Juni 2016, disetujui tanggal 20 Juni 2016

\section{CHARACTERISTIC, ASPIRATIONS, INFORMATION MEDIA IN DEVELOPMENT PLANNING CONSULTATION FORUMS AT THE BANJAR CITY, WEST JAVA PROVINCE}

\begin{abstract}
Demands and challenges in the era of democratization and decentralization have been a paradigm to change centralized development to participatory which gave more opportunities to aspirations of the people at local level. This is realized through a communication forum between stakeholders in the development planning consultation forum (Musrenbang). This study was aimed to describe and analyze the characteristics of stakeholder, aspirations and access to information media in Development Planning Consultation Forum (Musrenbang) at the village/urban village. This study used sequential mixed methods through the first and third stages of the research process using the descriptive qualitative method. Qualitative data were collected through direct observation, analysis of documents, and interviews, the informants had been chosen through purposive sampling, as well as the use of interactive analysis and SWOT analysis. The second stage uses the descriptive quantitative method. Quantitative data were collected through questionnaires and samples were taken gradually by using cluster sampling, Slovin formula, and stratified sampling and used descriptive analysis. The results showed the stakeholders have old age category and fairly low educational status, but they have a lot of experience in organizing and participating in Musrenbang and also have strong motive to participation in Musrenbang. The aspirations of the Musrenbang sub-villages/suburban villages result have important category and stakeholders have the intensity of information media access through the letter from the local governance.
\end{abstract}

Keywords: characteristics of stakeholder, aspirations, information media, consultation forum

Abstrak. Tuntutan dan tantangan di era demokratisasi dan otonomi daerah telah terjadi
perubahan paradigma pembangunan dari sentralistik menjadi partisipatif yang memberikan
kesempatan lebih luas dan terbuka bagi aspirasi masyarakat di tingkat lokal. Hal tersebut
diwujudkan melalui forum komunikasi antar stakeholder dalam Musyawarah Perencanaan
Pembangunan (Musrenbang). Tujuan penelitian ini untuk mendeskripsikan dan menganalisis
karakteristik, aspirasi, dan akses media informasi dalam Musrenbang desa/kelurahan. Penelitian
menggunakan metode campuran sekuensial (sequential mixed methods) dengan tahap pertama
dan ketiga proses penelitian menggunakan metode kualitatif deskriptif. Pengumpulan data
kualitatif melalui observasi langsung, analisis dokumentasi dan wawancara dengan pemilihan DOI: 10.20422/jpk.v19i1.54 
informan secara purposive sampling serta menggunakan analisis interaktif dan analisis SWOT. Tahap kedua menggunakan metode kuantitatif deskriptif. Data kuantitatif melalui kuesioner dengan pengambilan sampel secara bertahap yaitu sampling klaster, rumus Slovin dan sampel berstrata serta menggunakan analisis deskriptif. Hasil penelitian menunjukan karakteristik stakeholder memiliki kategori usia tua, tingkat pendidikan rendah, tetapi sangat berpengalaman berorganisasi dan mengikuti Musrenbang serta motif yang kuat untuk mengikuti Musrenbang desa/kelurahan. Aspirasi paling penting adalah hasil Musrenbang desa/kelurahan dan stakeholder memiliki intensitas tinggi pada media informasi melalui surat resmi dari pemerintahan desa/kelurahan.

Kata kunci: karakteristik stakeholder, aspirasi, media informasi, musyawarah

\section{PENDAHULUAN}

Proses pembangunan melalui tahapan penyusunan rancangan awal rencana pembangunan yang menyeluruh dan terukur serta yang bersifat teknokratik yaitu ditentukan oleh Pemerintah dan Dewan Perwakilan Rakyat yang bersifat top-down. Tahap berikutnya kegiatan Musyawarah Perencanaan Pembangunan (Musrenbang) untuk menyelaraskan rencana pembangunan yang dihasilkan masing-masing jenjang pemerintahan untuk Rencana Pembangunan Jangka Panjang untuk dua puluh lima tahun, Rencana Pembangunan Jangka Menengah untuk lima tahun, Rencana Kerja Pemerintah dan Rencana Kerja Pemerintah Daerah untuk satu tahun yang bersifat bottom-up mulai dari tingkat desa dan kelurahan, kecamatan, kabupaten, kota serta provinsi, sampai akhirnya ke tingkat nasional. Hal tersebut dalam Undang-Undang Nomor 25 Tahun 2004 Tentang Sistem Perencanaan Pembangunan Nasional, Peraturan Pemerintah Nomor 40 Tahun 2006 Tentang Tata Cara Penyusunan Rencana Pembangunan Nasional, Peraturan Pemerintah Nomor 8 Tahun 2008 Tentang Tahapan, Tata Cara Penyusunan, Pengendalian dan Evaluasi Pelaksanaan Perencanaan Daerah, yang pelaksanaannya diatur dalam Peraturan Menteri Dalam Negeri Nomor 54 Tahun 2010, bahwa Musrenbang adalah forum antar stakeholder dalam rangka menyusun rencana pembangunan nasional dan daerah.

Perencanan dan pelaksanaan pembangunan yang sistematis dan komprehensif tersebut, memerlukan komunikasi partisipatif yang diperankan stakeholder untuk menyinergikan perencanaan dan pelaksanaan pembangunan masyarakat di tingkat desa dengan pemerintah lokal dan nasional. Menurut Mascarenhas et al. (2012) kebijakan pembangunan harus dapat mengartikulasikan kebijakan nasional dan lokal serta manajemen yang tepat untuk sumber daya alam, interkoneksi antar kota, pertumbuhan ekonomi dan identitas budaya. Age et al. (2012) menyatakan pembangunan nasional merupakan misi dari semua negara untuk mencapai tujuannya dengan mengawali proses pembangunan dari level grassroot yaitu melaksanakan pembangunan di pedesaan.

Pentingnya komunikasi partisipatif pemangku kepentingan dalam perencanaan dan pelaksanaan hasil pembangunan melalui proses Musyawarah Perencanaan Pembangunan (Musrenbang) sesuai dengan tujuan pembangunan Indonesia dalam Undang-Undang Nomor 17 Tahun 2007 Tentang Rencana Pembangunan Jangka Panjang Nasional (RPJPN) Tahun 2005-2025, bahwa visi pembangunan nasional menuju tahun 2025 yaitu Indonesia yang mandiri, adil, dan makmur.

Terdapat beberapa permasalahan dalam proses pembangunan dan Musrenbang, berdasarkan beberapa hasil penelitian: (1) Komunikasi partisipatif belum terimplementasi secara baik karena pelibatan pengambilan keputusan didominasi oleh elit desa dan fasilitator, dan tidak terjadi komunikasi timbal balik (dialog) dengan masyarakat, sehingga musyawarah terkesan hanya bersifat pengumuman atau sosialisasi 
satu arah (Muchlis, 2009). (2) Stakeholder kurang memiliki, bekerjasama secara sukarela dan memberikan informasi (Susanti, 2009). (3) Ketidakselarasan perencanaan dengan program dana anggaran (Koswara, 2010), Musrenbang masih bersifat sentralistik dengan top-down planning, ketidakmampuan fasilitator mengakomodasi aspirasi dan hasil usulan kurang berkualitas (Ma'rif et al., 2010). (4) Musrenbang bersifat formal rutin tahunan dan belum dapat mengakomodasi kebutuhan masyarakat (Satries, 2011). (5) Ketidakseimbangan dalam informasi dan kesalahan sasaran informasi, maka akan membawa dampak terbengkalainya potensi dari rakyat perdesaan (Age et al., 2012). (6) Pemerintah masih mendominasi dalam Musrenbang (Indrajat et al., 2012). (7) Kelemahan peranan komunikator dari aspek kemampuan komunikasi (Salahuddin, 2012). (8) Perencanaan pembangunan daerah cenderung elitis, usulan dari masyarakat kurang diakomodir dan masyarakat tidak dilibatkan sampai kepengambilan keputusan perencanaan (Supardi, 2013).

Berdasarkan permasalahan hasil penelitian terdahulu, penelitian ini memiliki perbedaan yaitu memfokuskan kajian pada karakteristik pemangku kepentingan, aspirasi dan media informasi dalam Musrenbang desa/kelurahan. Maka penting untuk meneliti tentang: (1) Karakteristik stakeholder, aspirasi dan akses media informasi dalam Musrenbang desa/kelurahan. Stakeholder merupakan representasi masyarakat dalam proses pembangunan yang partisipatif mulai dari perencanaaan dan pelaksanaan di tingkat lokal yaitu desa/kelurahan. Kesadaran elit politik maupun masyarakat tentang otonomi daerah merupakan hal yang penting untuk membangun representasi kekuasaan bersama yang menjunjung tinggi pluralisme dan menghargai perbedaan di masyarakat (Susanto, 2010). Partisipatif melibatkan warga masyarakat desa dalam segenap proses pembangunan mulai dari perencanaan, pelaksanaan, pengendalian dan pemanfaatan hasil-hasilnya (Adisasmita, 2006). Pendekatan partisipasi sangat penting mengingat masyarakat di daerah yang lebih mengetahui dan mampu mengidentifikasi permasalahan, potensi, dan kebutuhan wilayahnya mulai dari perencanaan, pelaksanaan, bahkan penilaian suatu pembangunan (Purwaningsih, 2008). (2) Aspirasi yang diperjuangkan pemangku kepentingan dalam Musrenbang desa/kelurahan berupa usulan program pembangunan secara partisipatif. Realitas pembangunan yang partisipatif dengan adanya usulan aspirasi mulai dari tingkat Rukun Tetangga (RT), Rukun Warga (RW), dusun/lingkungan dan desa/kelurahan terdapat dalam kegiatan Musrenbang desa/kelurahan. Kaelola (2009) menyatakan aspirasi adalah usulan, keinginan atau kehendak disertai harapan agar bisa tercapai. (3) Media informasi yang tersedia dan dapat diakses akan mendukung terhadap proses Musrenbang supaya dapat diketahui dan menjadi milik bersama baik stakeholder, pemerintah desa/kelurahan maupun masyarakat. Satries (2011) menegaskan pemerintah daerah dapat memberikan informasi dan melakukan sosialisasi seluasluasnya mengenai segala hal yang berkaitan dengan pelaksanaan Musrenbang kepada masyarakat secara umum. Informasi dan sosialisasi tersebut dapat dilakukan dengan menggunakan media.

Dengan demikitan, tujuan penelitian ini adalah mendeskripsikan dan menganalisis karakteristik, aspirasi, media informasi yang diakses stakeholder dalam Musrenbang desa/kelurahan di Kota Banjar Provinsi Jawa Barat.

\section{LANDASAN KONSEP}

Stakeholder dalam pembangunan dapat berperan sebagai aktor atau pelaku dan agen pembaharu dalam pembangunan, menurut Sumarto (2004) pembangunan sebagai proses interaksi (komunikasi) dan aksi (tindakan) yang terencana untuk lebih menyejahterakan kehidupan, tidak lepas dari peran aktor pembangunan itu sendiri. Aktor pembangunan yang dimaksud adalah para stakeholder atau stakeholder yang beraspirasi, mengakomodasi, bernegosiasi, 
melakukan lobi dan sosialisasi, membuat perencanaan, pelaksanaan sampai evaluasi pembangunan. Mardikanto (2010) juga menyebut pelaku-pelaku pembangunan sebagai stakeholder.

Komunikasi untuk pembangunan mensyaratkan ada pelaku pembangunan (development actors) yang harus terlibat dalam struktur yang berasal dari masyarakat dalam setiap tingkat proses dari perencanaan dan pelaksanaan proyek-proyek pembangunan (Buddenhagen dan Baldwin, 2012).

Teori komunikasi yang relevan dengan pembangunan partisipatif adalah model komunikasi konvergen yang menggambarkan adanya hubungan antara komponen utama dalam proses komunikasi. Penelitian ini mengutip atau mengadopsi teori komunikasi konvergensi Rogers dan Kincaid (1981) yang menyebutkan bahwa informasi dan pemahaman bersama (timbal balik) merupakan komponen utama dalam model komunikasi konvergensi. Proses informasi pada level individu yang menyangkut penerimaan, penafsiran, pemahaman, keyakinan atau kepercayaan dan tindakan yang membuat secara potensial, paling tidak suatu informasi baru untuk diproses lebih lanjut. Ketika informasi dibagikan oleh dua atau lebih partisipan, proses informasi akan membawa pada pemahaman bersama (timbal balik), kesepakatan bersama, dan tindakan kolektif.

Menurut Rogers (1985) proses reorientasi yang diperlukan bagi penelitian komunikasi, diharapkan dapat menggunakan kekuatan komunikasi untuk tujuan-tujuan yang lebih manusiawi. Schmeer (1999) menyatakan suatu proses sistematis untuk mengumpulkan dan menganalisis informasi kualitatif dalam menentukan kepentingan siapa yang harus diperhitungkan ketika mengembangkan dan/atau melaksanakan kebijakan atau program. Mulyana (2007) menyatakan komunikasi pembangunan yang harus dikembangkan adalah komunikasi pembangunan yang berorientasi kerakyatan dan humanistik yang menuntut dialog antara pihak-pihak yang punya gagasan pembangunan dengan subjek pembangunan yaitu masyarakat. Ndraha (2011) berpendapat bahwa jika hendak mencari dan menemukan makna suatu perilaku dan nilai aspirasi dari rakyat, maka harus menggunakan komunikasi dengan pendekatan kualitatif.

\section{METODE PENELITIAN}

Penelitian menggunakan metode campuran sekuensial (sequential mixed methods) yaitu menggabungkan penemuanpenemuan yang diperoleh mulai dari penelitian kualitatif terlebih dahulu, penelitian kuantitatif ataupun sebaliknya untuk saling melengkapi, memperluas serta mempertajam hasil penelitian (Creswell, 2009; Taddlie and Tashakkori, 2010). Proses penelitian ini dilakukan dengan tiga tahap, yaitu: (1) Menggunakan metode kualitatif deskriptif, membuka akses, proses perizinan, dan melakukan pendekatan untuk menjalin hubungan kepada subjek penelitian (pada tahun 2012-2013). Menentukan lokasi dan identifikasi responden atau informan penelitian (November 2013 sampai Maret 2014). (2) Penelitian kuantitatif deskriptif melalui penyebaran angket antara AgustusSeptember 2014 kepada responden yang menjadi sampel penelitian yaitu para peserta Musrenbang desa/kelurahan di lokasi penelitian Desa Balokang dan Kelurahan Mekarsari Kecamatan Banjar serta Desa Rejasari dan Kelurahan Mekarsari di Kota Banjar Provinsi Jawa Barat. Pengambilan sampel secara bertahap dengan sampel kuota, rumus Slovin dan proporsional random sampling, dari 200 populasi didapatkan 133 responden dengan menggunakan analisis deskriptif. (3) Menggunakan penelitian kualitatif untuk triangulasi data melalui wawancara dengan purposive sampling kepada stakeholder yang terlibat langsung dalam Musrenbang desa/kelurahan, melakukan pengamatan langsung dan dokumentasi pada Musrenbang desa/kelurahan antara JanuariMaret 2015 dengan analisis interaktif dari Miles dan Huberman (2007) dan analisis SWOT (Rangkuti, 2004; Adisasmita, 2006). 


\section{HASIL PENELITIAN DAN PEMBAHASAN}

Penelitian ini difokuskan pada Musrenbang di tingkat desa/kelurahan sebagai forum komunikasi stakeholder yang mewakili masyarakat di tingkat bawah yaitu untuk membahas dan menyepakati hasil musyawarah tingkat Rukun Warga (RW) dan dusun/lingkungan. Berdasarkan penyebaran kuesioner, identitas pemangku kepentingan sebagai peserta Musrenbang desa/kelurahan dari laki-laki lebih banyak jumlahnya di empat lokasi penelitiaan sebesar $77,44 \%$, jenis pekerjaan lebih banyak sebagai petani sebesar 35,34\% dan wiraswasta sebesar $33,83 \%$. Khusus pada Musrenbang desa/kelurahan terdapat keterwakilan pemangku kepentingan dari Badan Permusyawaratan Desa (BPD) dan Badan Usaha Milik Desa (BUMDes).

Stakeholder yang terlibat hadir sebagai peserta Musrenbang desa/kelurahan dapat berupa kelompok, organisasi, dan individu yang memiliki kepentingan/pengaruh dalam proses pengambilan keputusan/pelaksanaan pembangunan. Stakeholder yang dimaksud adalah unsur staf pemerintah desa/kelurahan khususnya bidang pemerintahan dan ekonomi pembangunan yang terkadang merangkap sebagai fasilitator.

Proses pembangunan melibatkan peran penting dari pemangku kepentingan (stakeholder) baik perorangan maupun kelompok dan organisasi yang secara aktif terlibat dalam kegiatan, terkena dampak positif dan negatif dari hasil pelaksanaan kegiatan (Iqbal, 2007; Nurcholis et al., 2009; Mardikanto, 2010). Berdasarkan hasil penentuan sampel dengan kuota, rumus Slovin dan proporsional random sampling dari jumlah populasi 200 stakeholder, maka dihasilkan 133 orang sebagai sampel penelitian untuk mengisi kuesioner penelitian.

\section{Karakteristik Stakeholder dalam Musrenbang Desa/Kelurahan}

Stakeholder dalam pembangunan dapat berperan sebagai aktor atau pelaku dan agen pembaharu dalam pembangunan, menurut
Sumarto (2004) pembangunan sebagai proses interaksi (komunikasi) dan aksi (tindakan) yang terencana untuk lebih menyejahterakan kehidupan, tidak lepas dari peran aktor pembangunan itu sendiri.

Karakteristik stakeholder dalam penelitian ini yaitu usia, pendidikan formal, pengalaman berorganisasi, pengalaman Musrenbang desa/kelurahan, motif mengikuti Musrenbang desa/kelurahan, sebagai disajikan pada tabel 1. Karakteristik stakeholder menurut usia umumnya memiliki kategori tua memiliki nilai positif jika dinilai berdasarkan kriteria Bappeda dan BPS (Kota Banjar dalam angka 2013) untuk kategori usia produktif adalah antara 15 sampai dengan 64 tahun, sedangkan usia > 65 tahun sudah masuk kategori usia tidak produktif. Gustina (2007) menyatakan ada kecenderungan bahwa semakin tua usia maka peran dalam jaringan untuk derajat keterhubungan (koneksi) dan derajat integrasi akan semakin intensif. Tingkat kesadarannya untuk berpartisipasi dan menempatkan diri dalam jaringan juga sudah cukup baik. Menurut hasil observasi di dalam kegiatan Musrenbang desa/kelurahan pada Januari 2014 dan 2015 untuk peserta dari kalangan pemuda sangat sedikit menurut dokumentasi pada daftar hadir di empat lokasi penelitian umumnya berjumlah delapan orang.

Berdasarkan hasil wawancara dengan informan AsH (46 tahun) sebagai perangkat desa yang berperan sebagai ketua panitia Musrenbang Desa Rejasari, menyatakan generasi muda banyak yang meninggalkan desa untuk bekerja di daerah atau kota lain. Pengurus lembaga kemasyarakatan dari para "sesepuh" yang sudah lama mengabdi di desa seperti petani, pedagang, dan pensiunan.

Partisipasi pemikiran yang berupa ide dari tokoh pemuda diharapkan lebih ditingkatkan lagi, yaitu dapat dilakukan dengan memberikan kesadaran bahwa sumbangan pemikiran dari tokoh pemuda biasanya akan melahirkan ide-ide yang baru dan lebih mewarnai dalam penyusunan perencanaan pembangunan di desa maupun kelurahan (Susanti, 2009). Menurut 
Klausmeire dan Goodwin (dalam Purwatiningsih et al., 2012) umur sebagai salah satu karakteristik penting yang terkait efisiensi dan efektifitas, sehingga pada usia produktif akan lebih mudah menerima perubahan, ide-ide dan inovasi yang diharapkan dapat meningkatkan produktifitas. Gustina (2007) menyatakan semakin muda usia maka semakin banyak saluran komunikasi yang digunakan.

Tabel 1

Jumlah dan Persentase Stakeholder dalam Musrenbang Desa/Kelurahan di Kota Banjar Provinsi Jawa Barat Tahun 2014

\begin{tabular}{|c|c|c|c|}
\hline Indikator & Kategori & Jumlah & $\begin{array}{c}\text { Persentase } \\
(\%)\end{array}$ \\
\hline \multirow[t]{3}{*}{ Usia } & Muda (25 - 45 tahun) & 42 & 31,58 \\
\hline & Tua (46 - 55 tahun) & 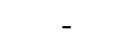 & \\
\hline & Sangat Tua ( $\geq 56$ tahun) & 91 & 68,42 \\
\hline \multirow[t]{3}{*}{ Pendidikan formal } & Rendah ( $\leq$ SD - SMP) & 119 & 89,47 \\
\hline & Menengah (SMA - Diploma) & - & \\
\hline & Tinggi ( $\geq \mathrm{S} 1)$ & 14 & 10,53 \\
\hline \multirow{2}{*}{$\begin{array}{l}\text { Pengalaman } \\
\text { berorganisasi }\end{array}$} & Tidak berpengalaman ( $\leq 1-2$ tahun $)$ & 45 & 33,83 \\
\hline & Berpengalaman ( $3-\geq 4$ tahun $)$ & 88 & 66,17 \\
\hline \multirow{2}{*}{$\begin{array}{l}\text { Pengalaman } \\
\text { Musrenbang }\end{array}$} & Tidak berpengalaman $(\leq 1-2$ tahun $)$ & 56 & 42,11 \\
\hline & Berpengalaman ( $3-\geq 4$ tahun $)$ & 77 & 57,89 \\
\hline \multirow{3}{*}{$\begin{array}{l}\text { Motif mengikuti } \\
\text { Musrenbang } \\
\text { desa/kelurahan }\end{array}$} & Menggantikan orang lain & 18 & 13,53 \\
\hline & Kepentingan masyarakat & 67 & 50,38 \\
\hline & Kepentingan organisasi & 48 & 36,09 \\
\hline
\end{tabular}

Sumber: diolah dari kuesioner penelitian.

Tingkat pendidikan dapat menentukan kompetensi dari sumber daya manusia. Menurut Ma'rif et al., (2010) karakteristik masyarakat yang masih rendah tingkat pendidikannya dan sebagian besar bermata pencaharian sebagai petani sehingga usulan yang dihasilkan kurang berbobot. Keterlibatan masyarakat yang memiliki pendidikan tinggi banyak yang tidak dapat menghadiri dalam pelaksanaan Musrenbang desa/kelurahan karena waktu penyelenggaraannya pada hari aktif kerja seperti PNS dan pegawai swasta serta pemerintah desa/kelurahan lebih memberikan kesempatan pada keterwakilan masyarakat yang banyak sebagai petani dan pedagang (wiraswasta). Hal tersebut dapat dilihat pada petikan hasil wawancara dengan informan.

Hasil wawancara dengan beberapa informan, di antaranya J (45 tahun) sebagai Sekretaris Desa Balokang menyatakan, kehadiran peserta Musrenbang desa lebih banyak diwakili oleh stakeholder dari petani dan pedagang atau wiraswasta yang menjadi mata pencaharian paling banyak serta menjabat sebagai ketua RT, RW, dan dusun. Menurut A (38 tahun) sebagai panitia Musrenbang kelurahan Muktisari menyatakan; stakeholder yang menjadi pegawai negeri atau swasta memiliki waktu yang terbatas dan biasanya aspirasi disalurkan pada waktu Musrenbang di tingkat RT, RW, dan lingkungan yang waktunya lebih fleksibel seperti pada malam hari.

Berdasarkan hasil pengamatan langsung dalam Musrenbang desa/kelurahan Januari 2014 dan 2015 terdapat beberapa stakeholder yang mendominasi dalam proses musyawarah, hal ini dikarenakan stakeholder tersebut memiliki keberanian dan kemampuan berkomunikasi untuk mengeluarkan aspirasi (pendapat), menjelaskan, menolak usulan, serta berdebat, kemudian memiliki pengalaman berorganisasi dan mengikuti 
Musrenbang desa/kelurahan. Indrajat et al., (2012) menyatakan Musrenbang masih bersifat formalitas tahunan, adanya dominasi dari beberapa stakeholder dan belum efektifnya pencapaian program yang dihasilkan.

Menurut Lubis (2007) komunikasi menuju komunitas pembelajar sebagai masyarakat yang komunikatif untuk berdialog sama rata, dan komunikasi (konvergensi) bukan "memenangkan argumentasi" tetapi untuk menumbuhkan dan mengembangkan pengertian. Purwatiningsih

(2012) menyatakan komunikasi akan berhasil dengan baik apabila pesan yang disampaikan sesuai dengan pengetahuan dan lingkup pengalaman komunikan.

\section{Aspirasi Stakeholder dalam Musrenbang Desa/Kelurahan}

Stakeholder membawa aspirasi pada Musrenbang desa/kelurahan untuk diusulkan, dimusyawarahkan, menyusun urutan prioritas dan menyepakati yang bersumber dari hasil Musrenbang di tingkat dusun/lingkungan yaitu pada proses musyawarah kelompok empat bidang pembangunan yaitu: (1) Bidang pemerintahan seperti pelatihan peningkatan kapasitas dan kompetensi untuk melakukan pelayanan masyarakat, kemampuan administrasi dan keuangan dari para aparatur lembaga masyarakat mulai RT, RW, dan dusun/lingkungan serta kesejahtaraannya; (2) Bidang sosial budaya seperti peningkatan kesadaran dan budaya bersih lingkungan dan kesehatan anak serta keluarga, pendidikan anak, keterampilan ibu rumah tangga, kegiatan keagamaan (kerohanian), dan pelestarian seni serta budaya lokal; (3) Bidang ekonomi seperti peningkatan kemampuan (keahlian), pendampingan, dan kemitraan untuk usaha kecil dan menengah, pertanian, perkebunan dan perikanan; (4) Bidang infrastruktur yaitu pengaspalan dan perbaikan jalan, pembuatan dan perbaikan jembatan, saluran air, dan gedung sebagai fasilitas umum.

Pada tabel 2 ditampilkan aspirasi yang diusulkan stakeholder pada Musrenbang desa/kelurahan di 4 (empat) lokasi penelitian.
Proses musyawarah tersebut merupakan model komunikasi konvergensi, sebagaimana menurut Rogers dan Kincaid (1981) ketika informasi dibagikan oleh dua atau lebih partisipan, proses informasi membawa pada pemahaman bersama (timbal balik), kesepakatan bersama, dan tindakan kolektif.

Aspirasi yang dibawa stakeholder di Musrenbang desa/kelurahan, merupakan proses dan hasil komunikasi melalui lobi secara informal dan telah dinegosiasikan serta disepakati. Orzeaţă, (2013) menyatakan sebagian besar orang berkomunikasi secara langsung baik lisan maupun tertulis, karena jenis komunikasi tersebut memberi mereka kesempatan untuk secara eksplisit menyampaikan pesan tentang tujuan dan kepentingan, serta cara-cara dan sarana yang mereka anjurkan dalam kompetisi atau negosiasi dengan pihak ketiga. Stakeholder sebagai peserta Musrenbang dusun lingkungan berasal dari berbagai unsur dalam masyarakat sebagai perwakilan organisasi masyarakat dan tokoh masyarakat, tetapi organisasi kemasyarakatan yang berasal dari ketua atau pengurus RT, RW, dan dusun/lingkungan serta tokoh masyarakat yang umumnya lebih banyak utusannya memiliki kepentingan untuk memerjuangkan aspirasi daerahnya daripada organisasi masyarakat yang utusannya umumnya lebih sedikit. Maka aspirasi berdasarkan kepentingan masyarakat dinilai lebih penting dibandingkan aspirasi dari kepentingan organisasi dan adanya penolakan pada aspirasi dianggap memihak kelompok tertentu serta aspirasi berdasarkan kepentingan pribadi sebagai aspirasi yang tidak penting. Menurut Sufianti et al. (2013) dalam proses perencanaan terdapat upaya untuk memecahkan permasalahan secara bersama, melalui suatu proses pembelajaran diantara para stakeholder. Proses interaksi, diskusi dan akomodasi aspirasi berkaitan dengan kepentingan, masalah dan strategi yang akan dilakukan.

Aspirasi berdasarkan program pembangunan yang belum terlaksanakan dan berdasarkan anggaran yang tersedia dinilai 
Tabel 2

Jumlah dan Persentase Aspirasi Stakeholder dalam Musrenbang Desa/Kelurahan di Kota Banjar Provinsi Jawa Barat Tahun 2014

\begin{tabular}{llcc}
\hline \multicolumn{1}{c}{ Aspirasi yang diusulkan } & \multicolumn{1}{c}{ Kategori } & Jumlah & $\begin{array}{c}\text { Persentase } \\
(\boldsymbol{\%})\end{array}$ \\
\hline Berdasarkan aspirasi pribadi & Tidak Penting & 86 & 64,66 \\
& Penting & 47 & 35,34 \\
Berdasarkan program pembangunan yang belum & Tidak Penting & 71 & 53,38 \\
terlaksanakan & Penting & 62 & 46,62 \\
Berdasarkan kepentingan masyarakat & Tidak Penting & 14 & 10,53 \\
& Penting & 119 & 89,47 \\
Berdasarkan hasil Musrenbang dusun/lingkungan & Tidak Penting & 7 & 05,26 \\
& Penting & 126 & 94,74 \\
Besaran anggaran yang tersedia & Tidak Penting & 78 & 58,65 \\
& Penting & 55 & 41,35 \\
Berdasarkan kepentingan organisasi & Tidak Penting & 58 & 43,61 \\
& Penting & 75 & 56,39 \\
Menolak aspirasi yang berpihak pada kelompok & Tidak Penting & 46 & 34,59 \\
tertentu & Penting & 87 & 65,41 \\
\hline
\end{tabular}

Sumber: Hasil pengolahan kuesioner.

sebagai aspirasi yang tidak penting, hal ini karena: (1) Aspirasi yang diusulkan selama ini umumnya dapat direalisasikan; (2) Aspirasi diusulkan semaksimal mungkin tanpa melihat besar anggaran, supaya jika ada penolakan masih terdapat program yang direalisasikan; (3) Aspirasi yang belum dilaksanakan, umumnya tidak diusulkan kembali dan fokus pada usulan yang baru, dikarenakan usulan program pembangunan tidak disetujui dan tidak sesuai dengan program rencana kota dan provinsi. Termasuk besaran anggaran yang diusulkan, akan disesuaikan dan ditentukan oleh APBD kota dan provinsi.

Aspirasi yang diperjuangkan stakeholder sampai pada hasil kesepakatan bersama dari proses musyawarah, dan adanya harapan bersama untuk mengusulkan kembali program yang tertunda pada tahun berikutnya secara berkesinambungan. Ini merupakan model komunikasi konvergensi, menurut Rogers dan Kincaid (1981) ada empat kemungkinan kombinasi dari pemahaman bersama (timbal balik) dan kesekapatan bersama yaitu: (1) Pemahaman timbal balik dengan kesepakatan; (2) Pemahaman timbal balik dengan ketidaksepakatan; (3) Kesalahpahaman timbal balik dengan kesepakatan; (4) Kesalahpahaman timbal balik dengan ketidaksepakatan.
Berdasarkan pengamatan pada Musrenbang desa/kelurahan bulan Januari tahun 2014 dan 2015, kegiatan musyawarah kelompok bidang fisik lebih lama waktu pelaksanaannya, lebih dinamis, dialogis, dan terjadi perdebatan serta keterlibatan stakeholder dari perempuan tidak ada. Hasil analisis dokumen dari program pembangunan yang dihasilkan Musrenbang desa/kelurahan 2014/2015 umumnya masih dominan program infrastruktur, termasuk pada program pemerintahan serta sosial budaya juga masih banyak usulan tentang pengadaan peralatan dan sarana operasional, dan pengadaan atau rehabilitasi ruangan yang bersifat fisik/material. Kecuali pada program ekonomi terdapat usulan tentang pengadaan, bantuan dan pemberdayaan bidang pertanian, peternakan, dan perikanan, akan tetapi dari segi jumlah pembiayaan anggaran masih jauh lebih sedikit dibandingkan dengan bidang infrastruktur.

\section{Akses Media Informasi}

Media informasi menurut Leeuwis (2009) adalah alat yang membantu menggabungkan saluran komunikasi yang berbeda yaitu: (1) Media massa konvensional seperti jurnal, brosur, buku, manual; (2) Media interpersonal seperti diskusi, pertemuan kelompok; (3) Media teknologi informasi seperti internet. Akses media 
informasi dari stakeholder disajikan pada tabel 3 .

Untuk mengetahui informasi tentang Musrenbang, stakeholder mengakses beberapa media informasi. Tabel 3 menunjukkan stakeholder memiliki intensitas tinggi dalam mengakses media informasi surat resmi dari pemerintah desa/kelurahan sebelum kegiatan Musrenbang desa/kelurahan dan pada pelaksanaan hasil. Intensitas mengakses media informasi yang masuk kategori rendah yaitu mengakses papan pengumuman di kantor desa/kelurahan, spanduk dan baliho di tempat umum, koran dan radio lokal, serta website Bappeda. Hal ini terjadi karena media papan pengumuman di kantor desa/kelurahan tidak dipergunakan untuk menginformasikan tentang Musrenbang. Media spanduk dan baliho tidak terpasang di tempat umum yang dapat dilihat oleh masyarakat, spanduk hanya dipergunakan sebagai dekorasi ruangan kegiatan Musrenbang. Radio dan koran lokal tidak dimanfaatkan dan tidak lagi sebagai sumber informasi utama, serta website Bappeda dapat diakses oleh kalangan terbatas yang mengerti dan mampu mengakses internet.

Media radio dan koran lokal tidak lagi menjadi media yang dipergunakan untuk mencari informasi, dan umumnya stakeholder masih terbatas kemampuannya mengakses media website Bappeda. Masyarakat memiliki keterbatasan dalam memiliki dan mengakses media lainnya seperti radio dan surat kabar. Media radio lokal dan surat kabar dinilai kurang efektif dan penting, sehingga tidak dimanfaatkan oleh pemerintah desa yang dampaknya hanya seketika atau cukup singkat, dan khalayak sudah jarang mengakses media radio. Media radio lokal tidak aktif melakukan peliputan pemberitaan, kecuali media surat kabar lokal pernah melakukan peliputan tentang proses dan hasil Musrenbang tetapi tidak intensif. Effendy (2005) menjelaskan bahwa media massa dalam perkembangannya dianggap tidak tepat lagi karena proses komunikasi dianggap tidak menyeluruh. Para cendekiawan menunjukkan gejala sosial yang diakibatkan media massa tidak hanya berlangsung satu tahap (one-step flow communication), tetapi dua tahap (twostep flow communication) dan multi-tahap (multistep flow communication) sebagaimana kecenderungan di daerah dan di perdesaan yang merupakan wilayah dari peranan para pemuka pendapat. Dalam era Teknologi Informasi dan Komunikasi (TIK), website Bappeda dapat memermudah dalam mencari informasi, mengajukan data usulan, mengontrol, dan mengevaluasi hasil Musrenbang. Media komunikasi massa termasuk pada dunia maya (cyberspace) dan saluran komunikasi tradisional lainnya, memainkan peran penting dalam menciptakan kesadaran ilmu pengetahuan dan teknologi (melalui penyebaran fakta, data, gambar) dalam bentuk apapun oleh media diinformasikan kepada khalayak, hal ini masih terdapat masalah dan tantangan (Batta et al., 2014).

Media informasi yang dapat dimanfaatkan dalam Musrenbang melalui strategi e-Gov dapat menciptakan: (1) Partisipasi masyarakat, artinya masyarakat dapat terlibat secara aktif salah satunya melalui fungsi media informasi yang sangat penting untuk memberikan ruang aspirasi dan mencerdaskan masyarakat untuk mengetahui persoalan, agenda pembangunan, mengontrol atau mengawasi, dan mengevaluasi proses pembangunan; (2) Transparansi, yaitu adanya keterbukaan informasi kepada publik melalui media informasi baik program pembangunan yang direncanakan, dilaksanakan, dan besarnya anggaran yang direalisasikan, sehingga masyarakat dapat mengetahui, mengontrol dan mengevaluasinya; Akuntabilitas, artinya mulai dari perencanaan, pelaksanaan dan evaluasi pembangunan dapat dipertanggungjawabkan kepada publik melalui media informasi.

\section{Strategi dalam Mendukung Kegiatan Musrenbang Desa/Kelurahan}

Berdasarkan deskripsi realitas karakteristik, aspirasi dan akses media informasi yang diakses stakeholder dalam proses dan pelaksanaan hasil Musrenbang desa/kelurahan dengan menggunakan analisis 
interaktif, maka dapat dibuat strategi Musrenbang desa/kelurahan dengan menggunakan analisis SWOT yaitu: (1) Faktor internal yang terdiri dari Strenght (kekuatan) dan Weakness (kelemahan). (2) Faktor eksternal terdiri dari Opportunities (peluang) dan Threats (ancaman) (Rangkuti,
2004; Adisasmita, 2006). Menurut Effendy (2008) strategi merupakan perencanaan dan manajemen untuk mencapai tujuan dengan teknik operasionalnya supaya dimengerti, diterima dan ada motivasi untuk melakukan.

Tabel 3

Jumlah dan Persentase Intensitas Mengakses Media informasi tentang Musrenbang Desa/Kelurahan

\begin{tabular}{|c|c|c|c|}
\hline \multirow[b]{2}{*}{ Parameter } & \multirow[b]{2}{*}{ Kategori } & \multicolumn{2}{|c|}{ Sebelum Musrenbang } \\
\hline & & Jumlah & $\begin{array}{l}\text { Persentase } \\
\quad(\%)\end{array}$ \\
\hline \multirow{2}{*}{$\begin{array}{l}\text { Mendapat informasi dari surat resmi } \\
\text { desa/kelurahan }\end{array}$} & Rendah & 26 & 19,55 \\
\hline & Tinggi & 107 & 80,45 \\
\hline \multirow{2}{*}{$\begin{array}{l}\text { Mendapat informasi Musrenbang dari papan } \\
\text { pengumuman di kantor desa/kelurahan }\end{array}$} & Rendah & 86 & 72,18 \\
\hline & Tinggi & 37 & 27,90 \\
\hline \multirow{2}{*}{$\begin{array}{l}\text { Mendapat informasi Musrenbang dari spanduk } \\
\text { dan baliho di tempat umum }\end{array}$} & Rendah & 127 & 95,49 \\
\hline & Tinggi & 6 & 04,51 \\
\hline \multirow[t]{2}{*}{ Mendapat informasi Musrenbang dari radio lokal } & Rendah & 114 & 85,71 \\
\hline & Tinggi & 19 & 14,29 \\
\hline \multirow[t]{2}{*}{ Mendapat informasi Musrenbang dari koran lokal } & Rendah & 109 & 81,95 \\
\hline & Tinggi & 24 & 18,05 \\
\hline \multirow{2}{*}{$\begin{array}{l}\text { Mendapat informasi Musrenbang dari website } \\
\text { Bappeda }\end{array}$} & Rendah & 92 & 69,17 \\
\hline & Tinggi & 41 & 30,83 \\
\hline
\end{tabular}

Sumber: Hasil pengolahan kuesioner.

Tabel 4

Analisis SWOT dan Strategi dalam mendukung Musrenbang Desa/Kelurahan

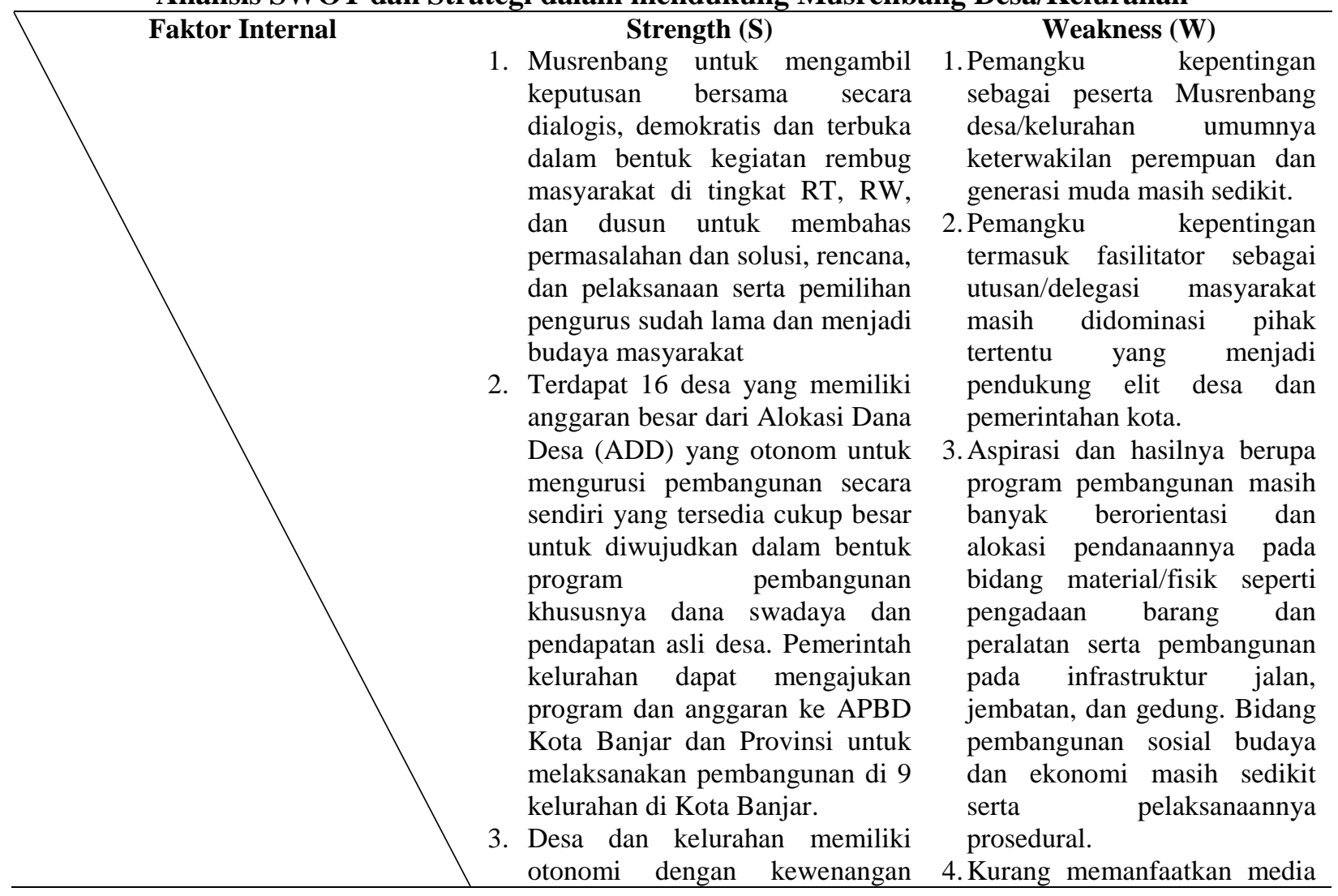




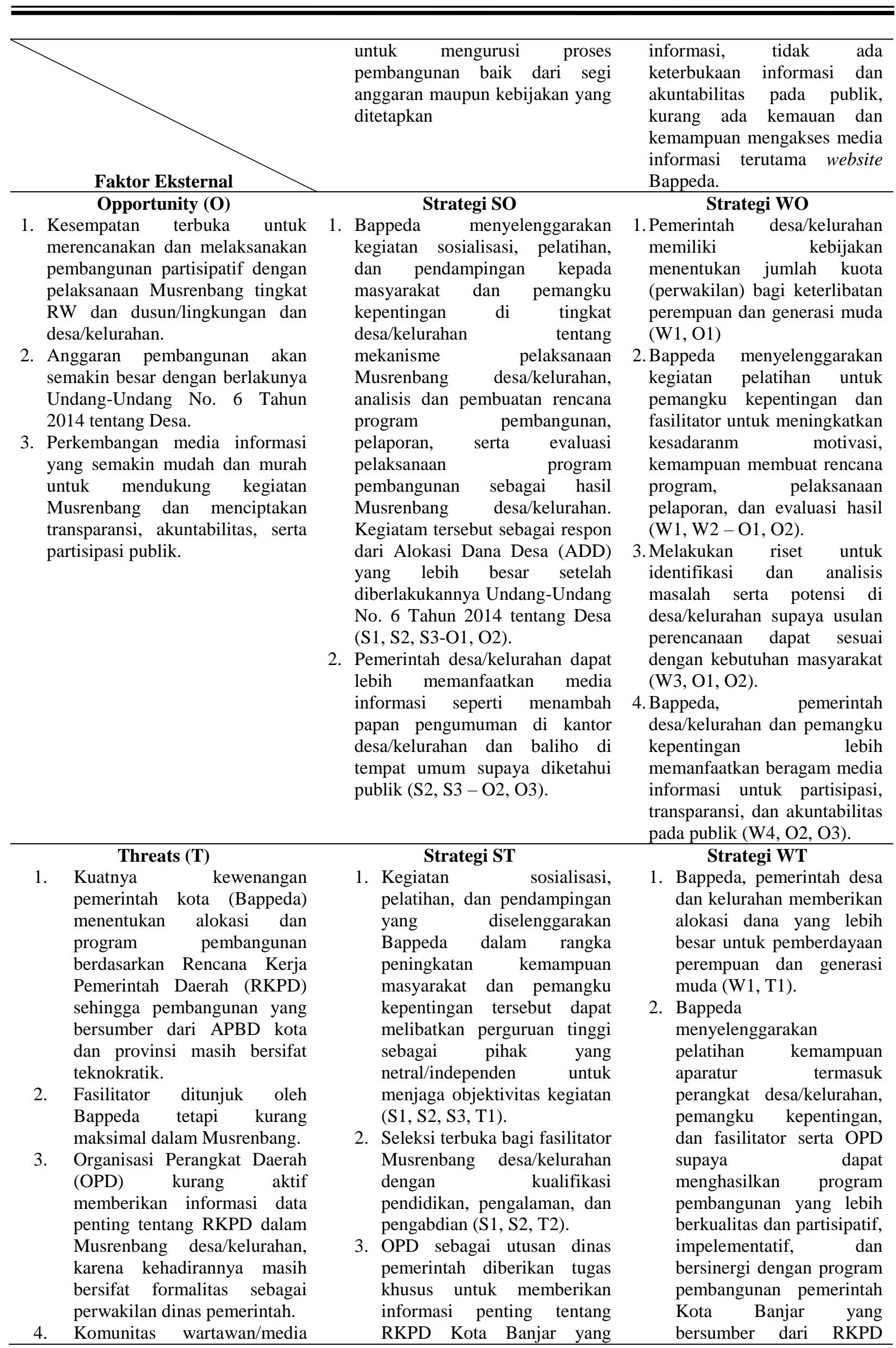


lokal dan Lembaga Swadaya Masyarakat (LSM) masih ada yang berorientasi proyek dan tidak konsisten melakukan kontrol secara objektif dan konstruktif bermanfaat bagi program dalam kegiatan Musrenbang desa/kelurahan (S1, S2, T3).

4. Menertibkan komunitas wartawan lokal dan LSM dengan mengimplementasikan Undang-Undang No. 40 Tahun 1999 tentang Pers dan Undang-Undang No. 17 Tahun 2013 tentang Organisasi Masyarakatan (S2, S3, T4).
(W2, W3, T1, T2, T3).

3. Bappeda menyelenggarakan sosialisasi kepada perangkat desa.kelurahan dan pemangku kepentingan tentang literasi media yaitu kebebasan pers, kode etik, jurnalistik, dan pemanfaatan media, serta kemampuan mengakses website Kota Banjar (W4, T4).
Berdasarkan hasil penelitian tahap pertama yaitu studi pendahuluan, tahap kedua menggunakan metode kuantitatif deskriptif dan tahap ketiga menggunakan metode kualitatif dengan triangulasi, dapat dikaji dengan analisis SWOT seperti ditunjukkan tabel 4.

\section{PENUTUP}

\section{Simpulan}

Identitas stakeholder sebagai peserta Musrenbang desa/kelurahan di Kota Banjar Provinsi Jawa Barat umumnya dari laki-laki, profesi petani dan pedagang. Karakteristik stakeholder umumnya dari usia tua, pendidikan rendah ( $\leq \mathrm{SD}-\mathrm{SMP})$, memiliki pengalaman berorganisasi dan mengikuti Musrenbang desa/kelurahan serta motif yang kuat mengikuti Musrenbang desa/kelurahan untuk kepentingan masyarakat dan organisasi. Masih terdapat dominasi dari beberapa stakeholder yang memiliki keberanian dan kemampuan berkomunikasi dalam proses musyawarah untuk beraspirasi, menolak, dan berdebat. Fasilitator masih ada yang kurang aktif berperan untuk memotivasi, memberikan informasi penting dan mengakomodasi aspirasi dalam Musrenbang desa/kelurahan.

Aspirasi stakeholder yang memiliki kategori penting adalah aspirasi yang berdasarkan hasil Musrenbang dusun/lingkungan, kepentingan masyarakat, menolak aspirasi yang berpihak pada kelompok tertentu dan aspirasi berdasarkan kepentingan organisasi. Aspirasi yang dihasilkan stakeholder yang memiliki kategori sesuai adalah aspirasi dari hasil Musrenbang dusun/lingkungan, usulan masyarakat, program pembangunan yang diprioritaskan dan usulan organisasi. Aspirasi stakeholder yang diusulkan dan dihasilkan masih dominan pada bidang fisik/infrastruktur, termasuk bidang lainnya seperti bidang pemerintah, sosial budaya dan ekonomi masih berorientasi pada material pengadaan barang, peralatan dan bantuan dibandingkan dengan program pemberdayaan masyarakat dan ekonomi serta pembangunan sumber daya manusia.

Aspirasi yang diusulkan dan disetujui pada bidang sosial budaya dan ekonomi dalam realisasinya masih bersifat prosedural dengan menunggu informasi yang lama dan mendadak serta harus membuat lagi proposal pengajuan ke dinas pemerintah Kota Banjar.

Intensitas stakeholder mengakses media informasi yang memiliki kategori tinggi yaitu mengakses media dari surat resmi pemerintah desa/kelurahan baik sebelum dan ketika pelaksanaan hasil Musrenbang desa/kelurahan. Media informasi lainnya seperti papan pengumuman di kantor desa/kelurahan, spanduk dan baliho di area publik, koran dan radio lokal serta website Bappeda Kota Banjar tidak dimanfaatkan oleh pemerintah dalam proses dan pelaksanaan hasil Musrenbang desa/kelurahan, sehingga intensitas stakeholder mengakses media informasi tersebut masuk kategori rendah. 


\section{Saran}

Pihak pemerintah desa/kelurahan memberikan kesempatan lebih terbuka dalam menentukan jumlah stakeholder dari perempuan dan generasi muda sebagai peserta Musrenbang desa/kelurahan.

Aspirasi stakeholder lebih berorientasi pada program pemberdayaan masyarakat dan pembangunan sumber daya manusia untuk meningkatkan pengetahuan serta kemampuan.

\section{DAFTAR PUSTAKA}

Adisasmita, R. (2006). Membangun desa partisipatif. Yogyakarta: Graha Ilmu.

Age, A. I., Obinne, C. P. O. and Demenongu, T. S. (2012). Communication for Sustainable Rural and Agricultural Development in Benue State, Nigeria. Sustainable Agriculture Research, 1 (1), p.118-129. [Online]. Available at: doi:10.5539/sar.v1n1p118.

Batta, H., Ashong, C. and Obot, C. (2014). Science, Nano-Science and NanoTechnology Content in Nigeria's Elite and Popular Press: Focus on Framing and Socio-political Involvement. New Media and Mass Communication, 31 (0), p.9-19. [Online]. Available at: doi:10.7176/NMMC.VOL319-19.

Buddenhagen, R. W. and Baldwin, J. R. (2012). Performing communicative functions in development projects: An exploratory study of development practices in Tanzania. International Journal of Intercultural Relations, 36 (3), p.418-429. [Online]. Available at: doi:10.1016/j.ijintrel.2011.11.001.

Creswell, J. W. (2009). Research Design: Qualitative, Quantitative, and Mixed Methods Approaches. 3rd ed. SAGE daparations.

Effendy, O. U. (2005). Ilmu Komunikasi Suatu Teori dan Praktik. Bandung: Remaja Rosdakarya.

Effendy, O. U. (2008). Dinamika komunikasi. Remaja Rosdakarya.

Gustina, A. (2007). Jaringan Komunikasi Dan Peran Perempuan Dalam Mempertahankan Budaya Barat (Studi Kasus Masyarakat Desa Negeri Katon, Kecamatan Negeri Katon, Lampung Selatan). Institut
Pertanian Bogor. [Online]. Available at: http://repository.ipb.ac.id/handle/12345678 9/41414.

Indrajat, H., Budihardjo, B., Hadi, I. and Budiono, P. (2012). Partisipasi Masyarakat Dalam Proses Pembangunan di Kecamatan Kemiling. In: Seminar Hasil-Hasil Penelitian dan Pengabdian Kepada Masyarakat- Dies Natalis FISIP Unila Tahun 2012, 2012, p.32-45. [Online]. Available at: http://publikasi.fisip.unila.ac.id/index.php/p rosem/article/view/4.

Iqbal, M. (2007). Analisis Peran Pemangku Kepentingan dan Implementasinya Dalam Pembangunan Pertanian. Jurnal Litbang Pertanian, 26 (3), p.89-99. [Online]. Available at: http://pustaka.litbang.pertanian.go.id/publik asi/p3263071.pdf.

Kaelola, A. (2009). Kamus istilah politik kontemporer. Yogyakarta: Cakrawala.

Koswara, A. (2010). The Alignment Strategy of $A P B D$ Planning with RPJMD to Improve Infrastructure Development in Bekasi City. Institut Pertanian Bogor. [Online]. Available at: http://repository.ipb.ac.id/handle/12345678 9/56809.

Leeuwis, C. (2009). Komunikasi untuk Inovasi Pedesaan: Berpikir Kembali tentang Penyuluhan Pertanian (dengan kontribusi dari Anne van den Ban). Kanisius.

Lubis, D. (2007). Komunikasi Menuju Komunitas Pembelajar. In: Adiwibowo, S. (ed.), Ekologi Manusia, Bogor: FEM IPB.

Ma'rif, S., Nugroho, P. and Wijayanti, L. (2010). Evaluasi Efektivitas Pelaksanaan Musyawarah Perencanaan Pembangunan (MUSRENBANG) Kota Semarang. Riptek, 4 (11), p.53-62. [Online]. Available at: http://bappeda.semarangkota.go.id/uploade d/publikasi/Evaluasi_Efektivitas_Pelaksana an_Musyawarah_Perencanaan_Pembangun an_(Musrenbang)_Kota_Semarang__SAMSUL._M_dkk.pdf.

Mardikanto, T. (2010). Komunikasi Pembangunan: Acuan Bagi Akademisi, Praktisi, dan Peminat Komunikasi Pembangunan. Sebelas Maret University Press.

Mascarenhas, A., Ramos, T. B. and Nunes, L. (2012). Developing an integrated approach for the strategic monitoring of regional spatial plans. Land Use Policy, 29 (3), 
p.641-651. [Online]. Available at: doi:10.1016/j.landusepol.2011.10.006.

Miles, M. B. and Huberman, A. M. (2007). Analisis Data Kualitatif (pen. Tjetjep Rohendi Rohidi). Jakarta: Penerbit Universitas Indonesia.

Muchlis, F. (2009). Analisis komunikasi partisipatif dalam program pemberdayaan masyarakat (studi kasus pada implementasi musyawarah dalam PNPM mandiri perdesaan di desa Teluk kecamatan Pemayung Kabupaten Batang Hari). Institut Pertanian Bogor. [Online]. Available at: http://repository.ipb.ac.id/handle/12345678 9/4409.

Mulyana, D. (2007). Membangun Komunikasi Pembangunan yang Humanistik. In: Dilla, S. (ed.), Komunikasi Pembangunan: Pendekatan Terpadu, Bandung: Simbiosa Rekatama Media.

Ndraha, T. (2011). Kybernology (Ilmu Pemerintahan Baru). Rineka Cipta, Jakarta.

Nurcholis, H. and Herfan, D. (2009). Perencanaan Partisipatif Pemerintah Daerah. Grasindo.

Orzeață, M. (2013). Defective Communication and The Lack of Communication - Main Causes of Security Crises Between Communities Belonging to Different Cultures. International Journal of Communication Research, 3 (2), p.100109.

Purwaningsih, E. (2008). Partisipasi Masyarakat Dalam Pembangunan Desa. Jantra, 3 (6), p.443-452.

Purwatiningsih, S. D. (2013). Effectiveness of Communications Development in Conservation Communities round the National Park of Mt. Halimun Salak. IPB (Bogor Agricultural University).

Rangkuti, F. (2004). Analisis SWOT Teknik Membedah Kasus Bisnis: Reorientasi Konsep Perencanaan Strategis untuk Mencapai Abad 21. Jakarta: Gramedia Pustaka Utama.

Rogers, E. M. (1985). Komunikasi dan Pembangunan; Perspektif Kritis (pen. Dasman Nurdin). Jakarta: LP3ES.

Rogers, E. M. and Kincaid, D. L. (1981). Communication networks: toward a new paradigm for research. New York Free Press 1981.

Salahuddin. (2012). Pengaruh komunikasi interaksional terhadap partisipasi masyarakat dalam musyawarah perencanaan pembangunan di Kota Kendari. Jurnal Stimuli Ilmu Komunikasi, 3, p.70-78.

Satries, W. I. (2011). Mengukur Tingkat Partisipasi Masyarakat Kota Bekasi Dalam Penyusunan APBD Melalui Pelaksanaan Musrenbang 2010. Kybernan, 2 (2), p.89130. [Online]. Available at: http://www.ejournal-

unisma.net/ojs/index.php/kybernan/article/v iew/356.

Schmeer, K. (1999). Guidelines for Conducting a Stakeholder Analysis. Bethesda, MD: Partnerships for Health Reform, Abt Associates Inc.

Sufianti, E., Sawitri, D., Pribadi, K. N. and Firman, T. (2013). Collaborative Process In Communicative-Based Planning Within Uncollaborative Society. MIMBAR, The Journal of Social and Development, 29 (2), p.133-144. [Online]. Available at: http://ejournal.unisba.ac.id/index.php/mimb ar/article/view/390.

Sumarto, H. S. (2004). Inovasi, Partisipasi dan Good Governance: 20 Prakarsa Inovatif dan Partisipatif di Indonesia. Jakarta: Yayasan Obor Indonesia.

Supardi, U. S. (2013). Aplikasi Statistika dalam Penelitian Konsep Statistika yang Lebih Komprehensif. Jakarta: Change Publication.

Susanti. (2009). Pengaruh Partisipasi Masyarakat Terhadap Proses Musyawarah Perencanaan Pembangunan di Kecamatan Kapuas Kabupaten Sanggau. Jurnal Ilmu Administrasi, 6 (3).

Susanto, D. (2010). Strategi Peningkatan Kapasitas Modal Sosial dan Kualitas Sumberdaya Manusia Pendamping Pengembangan Masyarakat. Jurnal Komunikasi Pembangunan, 08 (1), p.7789.

Taddlie, C. and Tashakkori, A. (2010). Problematika dan Kontroversi Utama Seputar Penggunaan Metode Campuran dalam Ilmu-Ilmu Sosial dan Prilaku (pen. Daryatno). 